\title{
PENDEKATAN MATEMATIS DALAM MENGIDENTIFIKASI RENDAHNYA PEMAHAMAN PESERTA DIDIK DALAM MANAJEMEN WAKTU
}

\author{
Nursupiamin \\ Institut Agama Islam Negeri (IAIN) Palu \\ Jl. Diponegoro No. 23 Palu \\ E-mail: nursupia@gmail.com
}

\begin{abstract}
Abstrak
Teknologi bukan hanya memberikan dampak positif bagi pengunanya juga memperlihatkan dampak negatif yang tidak dapat dipandang sebelah mata. Salah satu dampak negatif tersebut adalah manajemen waktu. Manajemen waktu berperan penting dalam keberhasilan belajar peserta didik. Dalam kajian ini, penulis melakukan pendekatan matematis dalam mengidentifikasi rendahnya pemahaman peserta didik tentang manajemen waktu. Jenis pendekatan yang digunakan studi kepustakaan (Library Research) dengan metode pengumpulan data menggunakan dokumentasi untuk dianalisis melalui teknik analisis isi. Hasil kajian menunjukkan bahwa rendahnya pemahaman peserta didik dalam manajemen waktu dapat diidentifikasi melalui pendekatan matematis yaitu metode numerik, dengan tahapan: (1) Penetapan desain atau model penelitian; (2) Pencarian data pokok atau primer, yaitu teks sendiri; dan (3) Pencarian pengetahuan konstektual. Kajian ini di awali dengan analisis data kuantitatif. Data diperoleh melalui pemberian angket manajemen waktu dan tes hasil belajar. Pada analisis statistik deskriptif diperoleh deskripsi rata-rata skor. Sedangkan analisis statistik inferensial ditujukan untuk uji hipotesis dan uji regresi. Selanjutnya dilakukan implementasi metode numerik dalam menentukan indikator rendahnya pemahaman peserta didik tentang manajemen waktu. Pada akhir hasil kajian dilakukan tahap analisis kualitatif. Hasil temuan dari peneliti yang berbeda kemungkinan akan berbeda pula karena dapat dipengaruhi lokasi atau karakteristik individu peserta didik.
\end{abstract}

Kata Kunci,: Rendahnya Pemahaman, Manajemen Waktu, Pendekatan Matematis

\begin{abstract}
Technology not only has a positive impact on its users, it also shows negative impacts that cannot be underestimated. One of the negative impacts is time management. Time management plays an important role in the learning success of students. Time management plays an important role in the learning success of students. In this study, the authors take a mathematical approach in identifying poor understanding of students about time management. The type of approach used is library research with the method of collecting data using documentation to be analyzed through content analysis techniques. The results of the study show that poor understanding of students in time management can be identified through mathematical approaches such as numerical methods, with stages: (1) Determination of design or research model; (2) Searching for primary data, i.e. the texts themselves; and (3) Search for contextual knowledge. This study begins with quantitative data analysis. Data obtained through time management questionnaires and learning outcomes tests. In descriptive statistical analysis obtained a description of the average score. While inferential statistical analysis is intended for hypothesis testing and regression testing. Next is the implementation of numerical methods in identifying poor understanding of students about time management. At the end of the results of the study conducted a
\end{abstract}




\section{2 | Nursupiamin}

qualitative analysis phase. The findings of different researchers are likely to be different because they can be influenced by the location or individual characteristics of students.

Keywords: poor understanding of students, time management, mathematical approach

\section{Pendahuluan}

Karakteristik pembelajaran terlihat pada adanya interaksi antara pendidik dan peserta didik yang dalam prosesnya seorang pendidik dituntut mampu mengembangkan potensi-potensi peserta didik secara optimal melalui aktivitas belajarnya. Ainurrahman menegaskan bahwa agar aktivitas yang dilakukan pendidik dalam proses pembelajaran terarah pada upaya peningkatan potensi peserta didik secara komprehensip, maka pembelajaran harus dikembangkan sesuai dengan prinsip yang benar yang bertolak dari kebutuhan internal peserta didik untuk belajar. ${ }^{1}$ Dengan kata lain, keberhasilan pendidikan khususnya pada proses pembelajaran sebagian besar banyak dipengaruhi oleh variabel-variabel dari pribadi siswa itu sendiri.

Gambaran yang terlihat di lapangan pada masa sekarang ini, semua usia baik anak usia dini, kaum pelajar, maupun orang dewasa menunjukkan ketergantungan akan teknologi. Kemajuan teknologi bukan hanya memberikan dampak positif bagi pemakainya juga memperlihatkan dampak negatif yang tidak bisa hanya dipandang sebelah mata saja. Salah satu dampak negatif yang terasa adalah manajemen waktu. Manajemen waktu memiliki peranan besar dalam keberhasilan belajar peserta didik. Peserta didik yang tidak memiliki pemahaman manajemen waktu ditandai dengan perencanaan yang tidak terorganisasi, tidak jelas, tidak konsisten, tidak ada tujuan, dan kurang disiplin dalam menggunakan waktu. ${ }^{2}$

Waktu dipandang sebagai seluruh rangkaian saat yang telah berlalu, sekarang, maupun yang akan datang. ${ }^{3}$ Hakekatnya, waktu sedang mengurangi makna hidup manusia. Bahkan, kesengsaraan yang dialami manusia bukan karena berkurangnya harta, tetapi karena membiarkan waktu berlalu tanpa makna. ${ }^{4}$ Begitu sangat pentingnya arti waktu, permasalahan ibadah dikaitkan dengan waktu-waktu tertentu. Pelaksanaan ibadah yang tidak sesuai dengan ketentuan waktu akan menimbulkan pertanyaan akan valid atau tidaknya ibadah tersebut. Sebagai contoh, mengenai kewajiban shalat, yang sudah ditentukan waktunya oleh Allah. ${ }^{5}$ Dengan demikian, diperlukan adanya pengontrolan waktu dalam melakukan kegiatan yang telah direncanakan.

\footnotetext{
${ }^{1}$ Ainurrahman. Belajar dan Pembelajaran. (Bandung : Alfabeta, 2013), h.113.

2 Diana Dwi Nurhidayati. 2016. Peningkatan Pemahaman Manajemen Waktu Melalui Bimbingan Kelompok Dengan Teknik Problem Solving pada Siswa. Jurnal Psikopedagogia, Vol. 5, No. 1 : 24-32. (diakses 24 Juli 2019).

3 M Quraish Shihab. Lentera Al-Quran: Kisah dan Hikmah Kehidupan. (Bandung : Mizan Pustaka, 2008), h. 87

${ }^{4}$ Toto Tasmaran. Kecerdasan Ruhaniah. (Jakarta: Gema Insani Press, 2001), h. 154.

5 Nadirsyah Hosen dan Nurussyariah Hammado. Ashabul Kahfi Melek 3 Abad Ketika Neurosains dan Kalbu Menjelajah Al-Quran. (Jakarta : Noura Book Publising, 2013), h.121.
} 
Purwanto berpendapat bahwa manajemen waktu adalah proses harian yang digunakan untuk membagi waktu, membuat jadwal, daftar halhal yang harus dilakukan, pendelegasian tugas, dan sistem lain yang membantu untuk menggunakan waktu secara efektif. ${ }^{6}$ Berdasarkan pengertian ini, peserta didik dituntut melakukan pengontrolan waktu dalam melakukan aktivitas apapun yang telah direncanakan dan ditargetkan sebelumnya. Hal ini diperkuat tulisan Rohadi (dalam Nurhidayati) pada hasil riset Jithendra M. Mishra dan Prabhakara Mishra yang menyimpulkan ada lima bidang utama yang tidak boleh ditinggalkan dalam pengelolaan waktu atau manajemen waktu, yaitu: (1) kesadaran bahwa sebagian besar waktu yang dihabiskan bersifat kebiasaan; (2) penentuan sasaran pribadi sangat penting bagi manajemen yang benar; (3) prioritas harus dikategorikan dan dikaji; (4) komunikasi yang baik dan benar sangat esensial; (5) menangguhkan mungkin merupakan halangan terbesar bagi pengelolaan waktu. $^{7}$

Dalam kajian ini, penulis melakukan pendekatan matematis dalam mengidentifikasi rendahnya pemahaman peserta didik dalam manajemen waktu melalui implementasi matematis dengan penekanan pada operasi aljabar, yang penyelesaian dapat diklasifikasikan berdasarkan analisis yang memenuhi persamaan awal, dilakukan dengan pendekatan numerik yang terlihat dalam bentuk suatu hampiran. Selain itu, ciri yang juga terlihat dari implementasi ini terdapat perhitungan secara iteratif. Implementasi tersebut dilakukan dengan metode numeric.

Berdasarkan latar belakang tersebut, permasalahan dalam tulisan ini fokus melihat bagaimana pendekatan metode numerik dalam mengidentifikasi rendahnya pemahaman peserta didik dalam manajemen waktu. Sehingga tujuan kajian ini adalah untuk mengetahui tahapan pendekatan metode numerik dalam mengidentifikasi rendahnya pemahaman peserta didik dalam manajemen waktu. Adapun yang diharapkan dari kajian ini dapat memberikan manfaat teoritis dan manfaat praktis. Manfaat teoritisnya adalah dapat menambah dan memperkaya ilmu pengetahuan dalam bidang pengajaran matematika dan manajemen waktu. Sedangkan manfaat praktisnya adalah dapat memberikan sumbangan ilmiah dalam meningkatkan aspek-aspek yang dapat meningkatkan pemahaman manajemen waktu peserta didik, dan memberikan informasi kepada pembaca tentang penyebab utama rendahnya pemahaman peserta didik dalam manajemen waktu dalam upaya meningkatkan hasil belajar peserta didik.

Penelitian terdahulu yang relevan dengan kajian ini antara lain :

1. Penelitian yang dilakukan oleh Yuniarsi Rahayu, pada tahun 2011 yang berjudul "Penerapan Metode Numerik Pada Peramalan untuk Menghitung Kooefisien-Koefisien pada Garis Regresi Linier Berganda” yang menyimpulkan bahwa:

${ }^{6}$ Sigit Purwanto. Pocket Mentor Manajemen Waktu. (Jakarta: Esensi Erlangga Group, 2008), h.6.

7 Diana Dwi Nurhidayati, h.27 


\section{4 | Nursupiamin}

a) Permasalahan yang dibahas ini, adalah suatu kasus dengan satu perubah terikat $(\mathrm{Y})$ dan tiga perubah $\mathrm{X}_{1 \mathrm{i}}, \mathrm{X}_{2 \mathrm{i}}, \mathrm{X}_{3 \mathrm{i}}$.

b) Penggunaan Metode Numerik dalam menghitung koefisien-koefisien pada regresi linier berganda.

c) Metode yang digunakan di sini adalah Metode Cramer, Metode Eliminasi Gauss-Jordan, Metode Matriks Balikan yang menghasilkan 4 persamaan linier dengan 4 variabel.

d) Penggunaan Matlab dalam perhitungan dengan Metode Cramer, Metode Eliminasi Gauss-Jordan, Metode Matriks Balikan dalam menghitung koefisien-koefisien pada regresi linier berganda.

e) Pada makalah ini hasil perhitungan koefisien-koefisien regresi linier berganda yang diperoleh dari penggunaan 3 metode tersebut adalah sama yaitu $\mathrm{a}_{0}=9.9958 ; \mathrm{a}_{1}=0.5502 ; \mathrm{a}_{2}=0.0552 ; \mathrm{a}_{3}=0.4609$ sehingga persamaan regresi linier berganda adalah $\mathrm{Y}=9.9958+0.5502 \mathrm{X}_{1}+$ $0.0552 \mathrm{X}_{2}+0.4609 \mathrm{X}_{3}$

f) Kesalahan baku (standard error) regresi adalah 2.07928

2. Kajian yang dilakukan oleh Diana Dwi Nurhidayati pada tahun 2016 yang berjudul "Peningkatan Pemahaman Manajemen Waktu Melalui Bimbingan Kelompok Dengan Teknik Problem Solving pada Siswa". Adapun hasil kajian tersebut menunjukkan bahwa : layanan bimbingan kelompok dengan teknik problem solving dapat meningkatkan pemahaman manajemen waktu pada siswa kelas VII A SMP Muhammadiyah 4 Yogyakarta. Hasil penelitian ini dapat bermanfaat bagi guru bimbingan dan konseling sebagai bahan pertimbangan dalam meningkatkan pemahaman manajemen waktu siswa melalui layanan bimbingan kelompok dengan teknik problem solving. ${ }^{9}$

Berdasarkan kedua penelitian tersebut terlihat persamaan dan perbedaan dengan kajian yang dilakukan penulis yang dapat dilihat dalam tabel berikut:

Tabel 1 : Persamaan dan Perbedaan dengan Penelitian Terdahulu yang Relevan

\begin{tabular}{|c|c|c|c|c|}
\hline \multirow[b]{2}{*}{ No } & \multirow{2}{*}{$\begin{array}{l}\text { Penelitian } \\
\text { terdahulu } \\
\text { yang } \\
\text { relevan }\end{array}$} & \multicolumn{2}{|l|}{ Perbedaan } & \multirow[b]{2}{*}{ Persamaan } \\
\hline & & $\begin{array}{l}\text { Variabel yang } \\
\text { berbeda }\end{array}$ & Kajian Penulis & \\
\hline 1 & $\begin{array}{l}\text { Yuniarsi } \\
\text { Rahayu }\end{array}$ & $\begin{array}{lr}\text { 1. Fokus penelitian } \\
\text { pada Peramalan } \\
\text { untuk Menghitung } \\
\text { Kooefisien- } \\
\text { Koefisien pada } \\
\text { Garis Regresi } \\
\text { Linier Berganda }\end{array}$ & $\begin{array}{l}\text { 1. Fokus } \\
\text { penelitian pada } \\
\text { identifikasi } \\
\text { rendahnya } \\
\text { pemahaman } \\
\text { peserta didik } \\
\text { dalam } \\
\text { manajemen } \\
\text { waktu }\end{array}$ & $\begin{array}{l}\text { Penerapan } \\
\text { Metode } \\
\text { Numerik }\end{array}$ \\
\hline
\end{tabular}

3 Yuniarsi Rahayu. 2011. Penerapan Metode Numerik Pada Peramalan untuk Menghitung Kooefisien-Koefisien pada Garis Regresi Linier Berganda. Seminar Nasional Teknologi Informasi \& Komunikasi Terapan 2011 (Semantik 2011). (diakses 24 Juli 2019).

${ }_{9}$ Diana Dwi Nurhidayati, h.31 
Identiikasi Rendahnya Pemahaman Peserta Didik terhadap Manajemen Waktu |5

\begin{tabular}{|c|c|c|c|c|}
\hline 2 & $\begin{array}{l}\text { Diana Dwi } \\
\text { Nurhidayati }\end{array}$ & $\begin{array}{l}\text { 1. Jenis penelitian } \\
\text { menggunakan } \\
\text { pendekatan } \\
\text { penelitian } \\
\text { tindakan kelas } \\
\text { (classroom action } \\
\text { research) dengan } \\
\text { jenis cross } \\
\text { sectional. } \\
\text { 2. Variable lain yang } \\
\text { terlibat Bimbingan } \\
\text { Kelompok Dengan } \\
\text { Teknik Problem } \\
\text { Solving }\end{array}$ & $\begin{array}{l}\text { 1. Jenis } \\
\text { penelitian } \\
\text { kajian pustaka } \\
\text { 2. Variable lain } \\
\text { yang terlibat } \\
\text { pendekatan } \\
\text { matematis } \\
\text { dalam } \\
\text { mengidentifika } \\
\text { si rendahnya } \\
\text { pemahaman } \\
\text { peserta didik }\end{array}$ & $\begin{array}{l}\text { Manajemen } \\
\text { Waktu }\end{array}$ \\
\hline
\end{tabular}

Sesuai kata kunci dari kajian ini, maka kajian teoritik terdiri atas pemahaman manajemen waktu dan pendekatan matematis.

Sardiman mendefinisikan pemahaman sebagai menguasai sesuatu dengan pikiran, yang berarti harus mengerti secara makna, maksud dan implikasinya serta aplikasinya, sehingga menyebabkan siswa dapat memahami suatu situasi. ${ }^{10}$ Manajemen merupakan sebuah pengambilan keputusan. Manajer harus menentukan tujuan yang akan dicapai, menentukan pihak, waktu, dan cara melaksanakan pekerjaan untuk mencapai tujuan yang telah ditentukan. ${ }^{11}$ Waktu dipandang sebagai seluruh rangkaian saat yang telah berlalu, sekarang, maupun yang akan datang. ${ }^{12}$ Berdasarkan ketiga kutipan tersebut dapat dikatakan pemahaman manajemen waktu adalah penguasaan suatu tindakan seseorang dalam mencapai sasaran-sasaran utama dalam kehidupan dengan menggunakan waktu seefektif dan seefisien mungkin.

Menurut KBBI, pendekatan adalah proses, cara, perbuatan mendekati. ${ }^{13}$ Sedangkan matematis adalah hal yang bersangkutan dengan matematika atau bersifat matematika. ${ }^{14}$ Berdasarkan kutipan tersebut pendekatan matematis dapat diartikan cara pandang secara matematis terhadap suatu permasalahan. Terkhusus dalam kajian ini, penulis menggunakan metode numerik sebagai pendekatan matematis dalam mengidentifikasi rendahnya pemahaman peserta didik dalam manajemen waktu.

Manajemen waktu dilakukan dengan melakukan pengawasan terhadap pengunaan waktu setiap kegiatan yang telah direncanakan sebelumnya. Jadi peserta didik dituntut melakukan pengontrolan waktu

h. 42

10 Sardiman. Interaksi dan Motivasi Belajar Mengajar. (Jakarta: Rajawali Pers, 2011), 1, 2014), h.4.

${ }^{11}$ John Suprihanto. Manajemen, (Yogyakarta: Gadjah Mada University Press, Cet. ke-

12 M Quraish Shihab, h. 87

13 https://kbbi.kemdikbud.go.id/entri/pendekatan. (diakses 2 Agustus 2019).

14 https://kbbi.kemdikbud.go.id/entri/matematis. (diakses 2 Agustus 2019). 


\section{6 | Nursupiamin}

dalam melakukan aktivitas apapun yang telah direncanakan dan ditargetkan sebelumnya. Hal ini diperkuat tulisan Rohadi (dalam Nurhidayati) pada hasil riset Jithendra M. Mishra dan Prabhakara Mishra yang menyimpulkan ada lima bidang utama yang tidak boleh ditinggalkan dalam pengelolaan waktu atau manajemen waktu, yaitu: (1) kesadaran bahwa sebagian besar waktu yang dihabiskan bersifat kebiasaan; (2) penentuan sasaran pribadi sangat penting bagi manajemen yang benar; (3) prioritas harus dikategorikan dan dikaji; (4) komunikasi yang baik dan benar sangat esensial; (5) menangguhkan mungkin merupakan halangan terbesar bagi pengelolaan waktu. ${ }^{15}$ Lebih lanjut dipaparkan, pedoman pokok manajemen waktu yang harus dipahami dan diterapkan siswa adalah cara mengelompokkan waktu untuk belajar. Siswa diharapkan dapat merencanakan dan menetapkan waktu belajar setiap hari agar terbiasa dengan jadwal yang telah dibuat sehingga siswa dapat memanfaatkan waktu dengan baik. ${ }^{16}$

Gie (Dalam Nurhidayati) menyebutkan ada empat teknik dalam memanfaatkan manajemen waktu untuk belajar: (1) siswa hendaknya menetapkan mata pelajaran yang akan dipelajarinya setiap hari sekurangkurangnya dua atau empat mata pelajaran setiap hari; (2) mengurutkan waktu mempelajari dua atau empat mata pelajaran itu menurut sukar mudahnya yang dikaitkan dengan kapan siswa mencapai waktu terbaik untuk belajar; (3) mengatur lamanya periode belajar sebaikbaiknya agar tidak terlampau pendek atau terlalu lama, berapa lama periode waktu belajar sebaiknya ditetapkan oleh individu bersangkutan; (4) belajar secara intensif untuk menguasai suatu mata pelajaran. ${ }^{17}$

Rahardi (dalam Nurhidayati) menjelaskan beberapa faktor yang menentukan tercapainya proses manajemen waktu siswa antara lain: (1) faktor dalam diri yang melakukan kesalahan; (2) faktor pandangan hidup (life way); (3) faktor lingkungan sekolah. Pemahaman manajemen waktu perlu diukur agar dapat dievaluasi atau diperbaiki. Menurut Hasan (dalam Nurhidayati) pemahaman diukur melalui tiga aspek pemahaman yaitu: (1) pemahaman sebagai bentuk penerimaan; (2) respon; dan (3) penilaian terhadap suatu objek. ${ }^{18}$

Metode numerik dipandang sebagai suatu teknik yang digunakan untuk memformulasikan persoalan matematik sehingga dapat dipecahkan dengan operasi perhitungan/aritmatika biasa (tambah, kurang, kali dan bagi). Pengertian ini didasari atas makna metode yang berarti cara dan numerik yang berarti angka. Sehingga secara harafiah, metode numerik adalah cara berhitung dengan menggunakan angka-angka. ${ }^{19}$ Metode numerik digunakan untuk menyelesaikan persoalan dimana perhitungan secara analitis tidak dapat digunakan atau sulit. Metode numerik ini berangkat dari pemikiran bahwa permasalahan dapat diselesaikan dengan menggunakan pendekatan-pendekatan yang dapat dipertanggungjawabkan secara analitik.

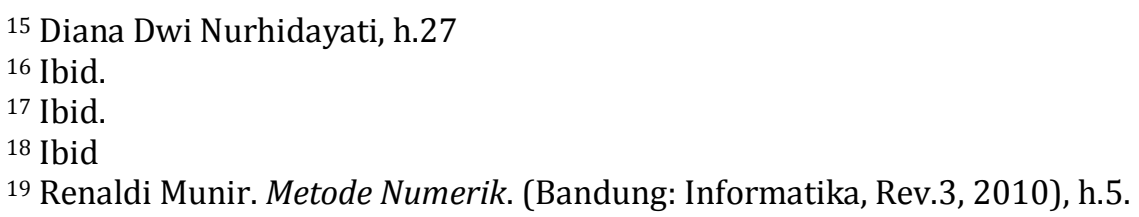


Metode numerik ini disajikan dalam bentuk algoritma-algoritma yang dapat dihitung secara cepat dan mudah.

Dasar pemikiran metode numerik tidak berbeda jauh dari dasar pemikiran analitis, hanya saja pemakaian grafis dan tehnik perhitungan yang mudah merupakan pertimbangan dalam pemakaian metode numerik. Mengingat bahwa algoritma yang dikembangkan dalam metode numerik merupakan algoritma pendekatan, maka dalam algoritma akan muncul istilah iterasi yaitu pengulangan proses perhitungan. Dengan kata lain, perhitungan dalam metode numerik adalah perhitungan yang dilakukan secara berulangulang untuk terus menerus memperoleh hasil yang makin mendekati nilai penyelesaian eksak. ${ }^{20}$

Adapun materi yang berkaitan dengan masalah penelitian adalah regresi linear. Metode regresi linear dimaksudkan digunakan untuk menentukan fungsi linier (garis lurus) yang paling sesuai dengan kumpulan titik data $\left(\mathrm{x}_{\mathrm{n}}, \mathrm{y}_{\mathrm{n}}\right)$ yang diketahui., seperti yang terlihat pada gambar berikut:

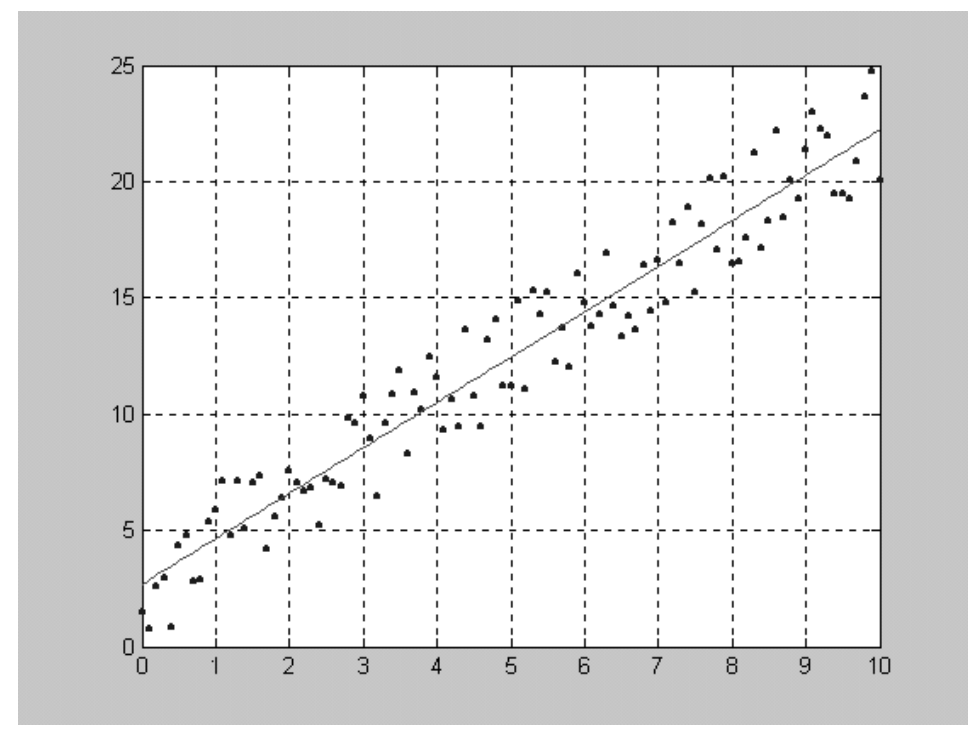

Gambar 1 : Sebaran Data Dengan Kurva Linier

Melalui gambar 1 , dalam regresi linier ini yang dicari adalah nilai $\mathrm{m}$ dan c dari fungsi linier $y=m x+c$, dengan:

$$
\begin{gathered}
m=\frac{N \sum_{n=1}^{N} x_{n} y_{n}-\left(\sum_{n=1}^{N} x_{n}\right)\left(\sum_{n=1}^{N} y_{n}\right)}{N \sum_{n=1}^{N} x^{2}-\left(\sum_{n=1}^{N} x_{n}\right)^{2}} \\
c=\frac{\sum_{n=1}^{N} y_{n}}{N}-m \frac{\sum_{n=1}^{N} x_{n}}{N}=\bar{y}-\mathrm{m} \bar{x}
\end{gathered}
$$

Adapun algoritma dalam regresi linear adalah sebagai berikut:

1. Tentukan $\mathrm{N}$ titik data yang diketahui dalam $\left(\mathrm{x}_{1}, \mathrm{y}_{1}\right)$ untuk $\mathrm{i}=1,2,3, \ldots, \mathrm{N}$

2. Hitung nilai $m$ dan $c$ dengan menggunakan formulasi dari regresi linear sebelumnya

3. Tampilkan fungsi linear

4. Hitung fungsi linear tersebut dalam range $\mathrm{x}$ dan step $\mathrm{dx}$ tertentu

${ }^{20}$ Achmad Basuki dan Nana Ramadijanti. Metode Numerik dan Algoritma Komputasi. (Yogyakarta: Andi Offset, 2005), h.5. 


\section{8 | Nursupiamin}

5. Tampilkan hasil tabel $\left(\mathrm{x}_{\mathrm{n}}, \mathrm{y}_{\mathrm{n}}\right)$ dari hasil fungsi linear tersebut Dengan demikian pada implementasi metode numerik, langkahlangkah yang ditempuh adalah :

1. Menyajikan data hasil belajar dan faktor-faktor penyebab rendahnya pemahaman manajemen waktu.

2. Memodelkan data dan menentukan solusi sesuai algoritma regresi linear.

3. Menganalisis output yang dihasilkan.

4. Langkah yang terakhir dalam metode penelitian adalah penarikan kesimpulan.

\section{Metode}

Pada kajian ini digunakan jenis/pendekatan yang berupa studi kepustakaan (Library Research). Kajian pustaka atau studi pustaka merupakan kegiatan yang mengembangkan aspek teoritis maupun aspek manfaat praktis. ${ }^{21}$ Kajian pustaka berfungsi untuk membangun konsep atau teori yang menjadi dasar studi dalam penelitian. ${ }^{22}$ Adapun beberapa sumber yang digunakan antara lain; buku-buku teks, jurnal ilmiah, refrensi statistik, hasil-hasil penelitian dalam bentuk skripsi, tesis, desertasi, dan internet, serta sumber-sumber lainnya yang relevan. ${ }^{23}$

Adapun metode pengumpulan data diambil dari sumber data dengan menggunakan dokumentasi. Apabila peneliti menggunakan dokumentasi, maka dokumen atau catatanlah yang menjadi sumber data, sedangkan isi catatan subjek penelitian atau variabel penelitian. ${ }^{24}$

Setelah data terkumpul maka penulis melanjutkan analisa data untuk menarik suatu kesimpulan. Dalam hal ini penulis gunakan teknik analisis isi dengan langkah-langkah sebagai berikut :

1. Penetapan desain atau model penelitian.

2. Pencarian data pokok atau data primer, yaitu teks sendiri. Sebagai analisis isi, teks merupakan objek yang terpokok.

3. Pencarian pengetahuan konstektual agar penelitian yang dilakukan tidak berada diruang hampa, tetapi terlihat kait mengait dengan faktor-faktor lain. ${ }^{25}$

${ }^{21}$ Sukardi. Metodologi Penelitian Pendidikan Kompetensi dan Praktiknya. (Jakarta : Bumi Aksara, 2013), h.33 2014), h.5

22 V.Wiratna Sujarweni. Metodologi Penelitian. (Yogyakarta : Pustaka Baru Perss,

${ }^{23}$ Anwar Sanusi. Metodologi Penelitian Bisnis. (Jakarta : Salemba Empat, 2016), h.32

${ }^{24}$ Suharsimi Arikunto. Prosedur Penelitian Suatu Pendekatan Praktik. (Jakarta : Rineka Cipta, 2006), h. 26

${ }^{25}$ Afifuddin dan Beni Ahmad Saebani. Metodologi Penelitian Kualitatif. (Bandung : Pustaka Setia, 2012), h.168 


\section{Identifikasi Rendahnya Pemahaman Manajemen Waktu Peserta Didik}

Penulis ketika telah mengumpulkan data hasil kajian dianalisis untuk mendapatkan kesimpulan dari hasil penelitian. Sehingga hasil analisis isi dipaparkan dengan langkah-langkah sebagai berikut :

1. Penetapan desain atau model penelitian.

Pada tahap penetapan desain untuk aplikasi penentuan identifikasi rendahnya pemahaman peserta didik dalam manajemen waktu maka desain penelitian yang diterapkan adalah penelitian mixed method. Hal ini dikarenakan mixed method menghasilkan fakta yang lebih komprehensif dalam meneliti masalah penelitian, karena peneliti memiliki kebebasan untuk menggunakan semua alat pengumpul data sesuai dengan jenis data yang dibutuhkan.

2. Pencarian data pokok atau data primer, yaitu teks sendiri. Sebagai analisis isi, teks merupakan objek yang terpokok.

Berkaitan dengan kajian ini, penulis menentukan variabel yang dilibatkan adalah variabel manajemen waktu dan variabel hasil belajar. Pemahaman teori dan konsep secara mendalam tentang kedua variabel tersebut harus betul-betul berdasarkan teori atau konsep yang digunakan. Hal ini berkaitan untuk penentuan indikator variabel yang berperan penting dalam menjawab persoalan dalam kajian ini.

3. Pencarian pengetahuan konstektual agar penelitian yang dilakukan tidak berada diruang hampa, tetapi terlihat kait mengait dengan faktor-faktor lain.

Menjadi hal yang sangat penting untuk diperhatikan bahwa data pokok yang berkaitan dengan kedua variabel tersebut harus benar adanya. Dan sebagai peneliti sebaiknya begitu setelah memperoleh data sebaiknya langsung diolah agar peneliti dapat segera mengetahui kelemahan data yang diperoleh. Jika data yang diperoleh kurang kuat, maka perlu dilakukan pengumpulan data tahap dua untuk membenarkan asumsi peneliti bahwa data yang diperoleh sesuai dengan kebutuhan peneliti.

Kajian ini bekerja dengan di awali analisis data secara kuantitatif, dimana data yang diperoleh dalam bentuk kuantitatif. Data ini diperoleh melalui pemberian instrumen angket atau observasi tentang manajemen waktu dan instrument tes (atau dokumentasi) hasil belajar peserta didik. Sebelum instrumen digunakan dilakukan analisis ujicoba.

Pada tahap ujicoba instrumen, dapat menggunakan uji validitas isi dan validitas item. Dalam validitas isi, lembar instrumen dinilai oleh validator. Pada format validasi observasi, aspek yang dinilai dapat mencakup petunjuk, cakupan aktivitas, dan bahasa yang digunakan. Sedangkan format observasi terbagi pada tiga kegiatan yaitu kegiatan awal, kegiatan inti, dan kegiatan penutup. Untuk format validasi tes, aspek yang dinilai dapat mencakup materi soal, konstruksi, dan bahasa. Sedangkan format tes mengandung kisikisi tes dengan memperhatikan kompetensi dasar, indikator, materi pokok, nomor soal, dan bobot soal. Selain kisi-kisi tes, format tes juga mengandung butir soal tes dengan memperhatikan petunjuk pengerjaan soal, soal, dan 


\section{0 | Nursupiamin}

kunci jawaban. Pada format angket mengandung kisi-kisi angket dengan memperhatikan variabel, komponen, indikator, nomor item penyataan (positif dan negatif), dan jumlah item. Dalam validasi item, umumnya hanya dilakukan pada ujicoba instrumen tes dan angkat.

Setelah instrumen dinyatakan valid, dilanjutkan dengan uji reliabilitas. Jika instrumen sudah memenuhi uji validitas dan reliabilitas, maka dilanjutkan dengan melakukan analisis statistik deskriptif dan analisis statistik inferensial. Pada analisis statistik deskriptif bertujuan memberikan gambaran secara umum mengenai rata-rata skor yang diperoleh yang dikaitkan dengan pengkategorian variabel.

Sedangkan analisis statistik inferensial ditujukan untuk uji hipotesis, dalam kajian ini digunakan uji regresi. Sebelum melakukan uji regresi terlebih dahulu dilakukan uji syarat yaitu uji normalitas dan uji linearitas. Pada tahap analisis ini berakhir ketika diperoleh hasil uji hipotesis dan persamaan regresi.

Setelah diperoleh persamaan regresi dari masing-masing indikator, selanjutnya dilakukan implementasi metode numerik dalam menentukan indikator rendahnya pemahaman peserta didik dalam manajemen waktu. Adapun tahapan implementasinya sebagai berikut :

1. Menentukan $\mathrm{N}$ titik data yang diketahui dalam $\left(\mathrm{x}_{1}, \mathrm{y}_{1}\right)$ untuk $\mathrm{i}=1,2,3, \ldots$, N. Pada tahap ini, misalkan diambil 86 titik data, dimana jumlah sampel yang diteliti ada 86 siswa.

2. Hitung nilai $\mathrm{m}$ dan $\mathrm{c}$ dengan menggunakan formulasi dari regresi linear sebelumnya.

3. Dalam regresi linier, nilai $m$ dan $c$ dari fungsi linier $y=m x+c$, ditentukan dengan menggunakan rumus berikut:

$$
\begin{gathered}
m=\frac{N \sum_{n=1}^{N} x_{n} y_{n}-\left(\sum_{n=1}^{N} x_{n}\right)\left(\sum_{n=1}^{N} y_{n}\right)}{N \sum_{n=1}^{N} x^{2}-\left(\sum_{n=1}^{N} x_{n}\right)^{2}} \\
c=\frac{\sum_{n=1}^{N} y_{n}}{N}-m \frac{\sum_{n=1}^{N} x_{n}}{N}=\bar{y}-\mathrm{m} \bar{x}
\end{gathered}
$$

Adapun perolehan nilai $\mathrm{m}$ dan $\mathrm{c}$ disajikan dalam bentuk tabel berikut :

Tabel 2 : Perolehan m dan c Melalui Metode Numerik

\begin{tabular}{|c|c|c|}
\hline Indikator & $\mathbf{m}$ & $\mathbf{c}$ \\
\hline 1 & & \\
\hline 2 & & \\
\hline 3 & & \\
\hline
\end{tabular}

Setelah diperoleh nilai $\mathrm{m}$ dan $\mathrm{c}$ maka dilanjutkan pada algoritma atau tahap berikutnya.

4. Menampilkan fungsi linear. Berdasarkan perolehan langkah 2 diperoleh fungsi linear dari masing-masing indikator disajikan seperti tabel berikut: 
Tabel 3 : Fungsi Linear dari Indikator Pemahaman Peserta Didik Dalam Manajemen Waktu

\begin{tabular}{|c|c|}
\hline Indikator & $\mathbf{y}$ \\
\hline 1 & \\
\hline 2 & \\
\hline 3 & \\
\hline
\end{tabular}

5. Menghitung fungsi linear tersebut dalam range $\mathrm{x}$ dan step $\mathrm{dx}$ tertentu Pada tahap ini diambil range $\mathrm{x}=[0,100]$ dengan $\mathrm{dx}=1$, maka diperoleh nilai perolehan pendekatan metode numerik dalam dalam menentukan indikator rendahnya pemahaman peserta didik dalam manajemen waktu. Melalui model persamaan regresi diperoleh pendekatan regresi dalam menentukan indikator rendahnya pemahaman peserta didik dalam manajemen waktu.

6. Menampilkan hasil tabel $\left(\mathrm{x}_{\mathrm{n}}, \mathrm{y}_{\mathrm{n}}\right)$ dari hasil fungsi linear tersebut

Hasil fungsi linear yang diperoleh dari metode numerik yang terlihat melalui tabel, berdasarkan tabel tersebut bahwa indikator yang dominan dalam menentukan rendahnya pemahaman peserta didik dalam manajemen waktu. Hasil tersebut dibandingkan dengan hasil secara statistik (regresi linear).

Setelah analisis data secara kuantitatif diperoleh, hasil kajian ini dianalisis secara kualitatif melalui pengujian teori untuk merumuskan teori baru yang peneliti temukan pada kasus tertentu. Pada hasil analisis data dapat memberikan hasil temuan yang berbeda yang dapat dipengaruhi faktor lokasi atau karakteristik individu peserta didik.

\section{Kesimpulan}

Berdasarkan pembahasan kajian, disimpulkan bahwa rendahnya pemahaman peserta didik dalam manajemen waktu dapat diidentifikasi melalui pendekatan matematis yaitu tahapan pendekatan metode numeric, dengan tahapan sebagai berikut : (1) Penetapan desain atau model penelitian; (2) Pencarian data pokok atau data primer, yaitu teks sendiri; dan (3) Pencarian pengetahuan konstektual. Kajian ini bekerja dengan di awali analisis data secara kuantitatif, dimana data yang diperoleh dalam bentuk kuantitatif. Data ini diperoleh melalui pemberian instrument angket atau observasi tentang manajemen waktu dan instrument tes (atau dokumentasi) hasil belajar peserta didik. Pada analisis statistik deskriptif digambarkan secara umum mengenai rata-rata skor yang diperoleh yang dikaitkan dengan pengkategorian variabel. Sedangkan analisis statistik inferensial ditujukan untuk uji hipotesis, dalam kajian ini dilakukan uji regresi. Setelah diperoleh persamaan regresi dari masing-masing indikator, selanjutnya dilakukan implementasi metode numerik dalam menentukan indikator rendahnya pemahaman peserta didik dalam manajemen waktu. Setelah tahap analisis data secara kuantitatif diperoleh, hasil kajian dianalisis secara kualitatif melalui pengujian teori untuk merumuskan teori baru yang ditemukan pada 
kasus tertentu, karena kemungkinan hal yang berbeda pada hasil temuan dari peneliti yang berbeda akan terlihat. Hal ini disebabkan dapat dipengaruhi faktor lokasi atau karakteristik individu peserta didik.

\section{Daftar Pustaka}

Achmad Basuki dan Nana Ramadijanti. Metode Numerik dan Algoritma Komputasi. Yogyakarta: Andi Offset, 2005.

Afifuddin dan Beni Ahmad Saebani. Metodologi Penelitian Kualitatif. Bandung : Pustaka Setia, 2012.

Ainurrahman. Belajar dan Pembelajaran. Bandung : Alfabeta, 2013.

Anwar Sanusi. Metodologi Penelitian Bisnis. Jakarta : Salemba Empat, 2016.

John Suprihanto. Manajemen, Yogyakarta: Gadjah Mada University Press, Cet. ke-1, 2014.

M Quraish Shihab. Lentera Al-Quran: Kisah dan Hikmah Kehidupan. Bandung : Mizan Pustaka, 2008.

Nadirsyah Hosen dan Nurussyariah Hammado. Ashabul Kahfi Melek 3 Abad Ketika Neurosains dan Kalbu Menjelajah Al-Quran. Jakarta : Noura Book Publising, 2013.

Renaldi Munir. Metode Numerik. Bandung: Informatika, Rev.3, 2010.

Sardiman. Interaksi dan Motivasi Belajar Mengajar. Jakarta: Rajawali Pers, 2011.

Sigit Purwanto. Pocket Mentor Manajemen Waktu. Jakarta: Esensi Erlangga Group, 2008.

Suharsimi Arikunto. Prosedur Penelitian Suatu Pendekatan Praktik. Jakarta : Rineka Cipta, 2006.

Sukardi. Metodologi Penelitian Pendidikan Kompetensi dan Praktiknya. Jakarta : Bumi Aksara, 2013.

Toto Tasmaran. Kecerdasan Ruhaniah. Jakarta: Gema Insani Press, 2001.

V.Wiratna Sujarweni. Metodologi Penelitian. Yogyakarta : Pustaka Baru Perss, 2014.

Diana Dwi Nurhidayati. 2016. Peningkatan Pemahaman Manajemen Waktu Melalui Bimbingan Kelompok Dengan Teknik Problem Solving pada Siswa. Jurnal Psikopedagogia, Vol. 5, No. 1: 24-32. (diakses 24 Juli 2019).

Yuniarsi Rahayu. 2011. Penerapan Metode Numerik Pada Peramalan untuk Menghitung Kooefisien-Koefisien pada Garis Regresi Linier Berganda. Seminar Nasional Teknologi Informasi \& Komunikasi Terapan 2011 (Semantik 2011). (diakses 24 Juli 2019).

https://kbbi.kemdikbud.go.id/entri/pendekatan. (diakses 2 Agustus 2019). https://kbbi.kemdikbud.go.id/entri/matematis. (diakses 2 Agustus 2019). 